\title{
WALT WHITMAN AND THE CULTURE OF PRAGMATISM
}

\author{
Daniel S. MalachuK
}

IN HIS 1955 BIOGRAPHY of Walt Whitman, The Solitary Singer, Gay Wilson Allen wrote that "Whitman's language and his thinking were awkward [in Democratic Vistas] . . . because ... he was exploring problems and presenting empirical answers that actually gave a preview of the main course of American philosophy for the next century[.] [F] or what," Allen suggested, "was this theory of 'Democracy' but the forerunner of William James's 'Pluralism' and John Dewey's 'Pragmatism'?"' Looking closely at William James's work in particular, one might make even stronger claims about Whitman's catalytic role in the genesis of pragmatism. Occasionally in his lectures on pragmatism, James suggests that Whitman is a pragmatist forerunner; and in fact he frequently draws upon Whitman to make arguments for the pluralistic worldview that for James went hand in hand with the philosophy of pragmatism. But Whitman's role may have been even more important, for there is evidence that it was Whitman's writing (in part) that first persuaded James to become a pragmatist. In other words, James used Whitman to persuade others to become pragmatists because it was Whitman himself who had persuaded James to become a pragmatist. Following an examination of this double role of Whitman's writing within the early history of pragmatism, this essay concludes with a discussion of the contemporary pragmatist Richard Rorty's use of Whitman, suggesting the poet's enduring importance to the culture of pragmatism.

In 1905, when James began to plan the lectures that he would deliver in 1906 and publish as Pragmatism in 1907, he jotted down these notes for himself: "Discuss . . . absolutism; demolish it. Set up pluralism as alternative." 2 The lectures were slightly more subtle in approach, but it is important to recall just how passionately James believed in the pragmatist's pluralistic worldview-and how passionately absolutists of all stripes feared it. The point of contention between these two camps was the nature of truth, which led in turn to debates about the nature of the universe and our place within it. If, as James and the other pluralis- 
tic pragmatists said, the universe was really pluralist, full of divergent experiences that no single truth-like God, or the One, or Being-could explain, was not truth itself, then, just something forged by humans for temporary use? So the absolutists worried, wondering what was to keep each of us - with our private temporary truths - from killing one other. Bertrand Russell argued this way in a famous essay he wrote in response to James's book. "[A]lthough it begins with liberty and toleration," Russell wrote, pragmatism "develops by inherent necessity into the appeal to force and [to] the big battalions." ${ }^{3}$ Another popular-science writer of the time, Edwin Slosson, linked James's pragmatism not to imperialism but to a breakdown of social order. "[T] he pragmatic method is like the invention of gunpowder," Slosson argued; "[i]n careless hands it may lead to intellectual anarchy."

James, too, believed that pragmatism was a modern invention of world-historical significance, but one not at all like imperialism or anarchy. As he wrote to his brother Henry in 1907:

I have just finisht the proofs of a little book called 'pragmatism' which even you may enjoy reading. . . . [I]n the midst of the literature of the way of thinking which it represents, . . . [it will] be treated later as 'representative.' I shouldn't be surprised if 10 years hence it should be rated as 'epoch-making,' for of the definitive triumph of that general way of thinking I can entertain no doubt whatever-I believe it to be something quite like the protestant reformation. ${ }^{5}$

So, even if James occasionally liked to say that pragmatism was technically just "a new name for an old way of thinking" (the modest subtitle to Pragmatism), he and many others really understood the philosophy of pragmatism to represent the crystallization of a way of thinking about the world, a culture, that was distinctly new: dedicated to the empirical, disdainful of absolutes and their systems, and relentlessly practical. For James, it was a culture worth fighting for. "I didn't know, until I came to prepare them," James wrote a friend while revising his lectures, "how full of power to found a 'school' and to become a 'cause,' the pragmatistic idea was. But now I am all aflame with it . . . and I mean to turn the lectures into a solid little cube of a book . . . which will, I am confident, make the pragmatic method appear ... as the philosophy of the future."6

The lectures themselves were a smashing success, drawing over five hundred people to their first reading in Boston at the end of 1906, and, a month later, over one thousand people to a reading at Columbia University. Still, James was acutely aware that many people-including members of his audiences - remained wary of pragmatism. So, even as he presented the early lectures in the series, he revised the later ones feverishly to address new fears that came up. One major fear of his audience was that the pragmatist's test of use for truths might determine that belief in God was useless. As James stated in this last lecture, "Prag- 
matism and Religion," "my previous lectures ... may have left the impression on many of you that pragmatism means methodically to leave the superhuman out." In this final lecture, he therefore hoped to show that pragmatism actually does see a use for a "melioristic type of theism" between "the two extremes of crude naturalism . . . and transcendental absolutism," a religion-James promised - that "is exactly what you require." Thus James began this last lecture anxious to persuade his audience that pragmatism did not rule out religious possibilities or even belief in an Absolute, admitting that "the use of the Absolute is proved by the whole course of men's religious history." ${ }^{8} \mathrm{He}$ then quotes Whitman.

At this point, it is important to recall that Whitman criticism in 1906, as Charles Willard describes in Whitman's American Fame, was defined by two poles: one that claimed he was a second-rate poet of sensuality, the other a first-rate genius of universal oneness, of absolutism. ${ }^{9}$ In the decade following his death in 1892 , the notion of Whitman as the bard of the Absolute was championed in particular by a band of followers-including R. M. Bucke and Horace Traubel-who saw Whitman as nothing less than the nineteenth-century Christ. Therefore when James begins to read thirty lines from Whitman's "To You" immediately after conceding that the Absolute had its uses in the past, his audience must have assumed that James was reading Whitman-as Bucke and Traubel did-as an absolutist. The last five of the lines that James read were the following:

Whoever you are! claim your own at any hazard!

The hopples fall from your ankles-you find an unfailing sufficiency;

Old or young, male or female, rude, low, rejected by the rest, whatever you are promulges itself;

Through birth, life, death, burial, the means are provided, nothing is scanted;

Through anger, losses, ambition, ignorance, ennui, what you are picks its way. ${ }^{10}$

A testament of faith in an "unfailing sufficiency," this poem no doubt led James's audience to believe they were to hear about the pragmatistic use of belief in an Absolute. ${ }^{11}$

However, concluding his reading, James instead announces that, actually, "there are two ways of taking [the poem], both useful," one of which is indeed that of the absolutist, which James then summarizes: "The glories and grandeurs, they are yours absolutely, even in the midst of defacements. Whatever may happen to you, whatever you may appear to be, inwardly you are safe. Look back, lie back, on your true principle of being!" 12 Then James introduces a second way:

But pragmatism sees another way to be respected also, the pluralistic way of interpreting the poem. The you so glorified . . . may mean your better possibilities phenomenally 
taken. . . . Forget the low in yourself, then, think only of the high. . . . [T]hrough angers, losses, ignorance, ennui, whatever you thus make yourself, whatever you thus most deeply are, picks its way. ${ }^{13}$

Here James echoes Whitman's "picks its way" to reinforce his own point about life within a pluralistic universe. Whitman's poem is not really about that absolute faith in "the static One," as James puts it; it is about picking moments from life, about seeing, as James says, "possibles in the plural, genuine possibles, ... [with] all the restlessness of that conception." 14 This latter view, James concludes, is that of the pragmatist:

Noble enough is either way of reading the poem; but plainly the pluralistic way agrees with the pragmatic temper best. . . . It sets definite activities in us at work. Altho this second way seems prosaic and earth-born in comparison with the first way, yet no one can accuse it of tough-mindedness in any brutal sense of the term. ${ }^{15}$

James began this lecture with Whitman's poem in order to convince his audience that pragmatism means neither a "brutal" or "toughminded" practicality, a surrender to the law of the jungle as Russell would claim, nor a passive worship of universal oneness. Instead, pragmatism means "restlessly" approaching the world as full of possibilities, none of them finalized, many of them available "to you." In this lecture from Pragmatism, in short, James relies upon Whitman's contemporary reputation as a mystic to ease his audience-frightened by a pragmatism associated with godless means-end thinking-from their own lazy absolutism into the more modern, pluralistic worldview of melioristic or progressive pragmatism.

This is the way James used Whitman in Pragmatism, because this is how, I believe, James himself had learned to read Whitman over the previous forty years. The first published reference to Whitman by James is in a letter to Oliver Wendell Holmes, Jr., in 1868, when James was only twenty-six. It is highly possible that James knew of Whitman even earlier. In 1865, when James was twenty-three, his brother Henry reviewed Drum-Taps (quite negatively) in the Nation. ${ }^{16}$ Indeed, James may have heard of Whitman as early as 1855 , when he was a precocious thirteen-year-old and his father's friend, Emerson, greeted the poet at the beginning of his career with his famous letter. James was also close friends with two slightly older men who were among Whitman's earliest reviewers: Charles Eliot Norton and William Dean Howells. ${ }^{17}$ In any case, James clearly knew Whitman by the mid-to-late 1860 s, a time when Whitman, as Charles Willard notes, was "a familiar figure in Washington streets ... [ [but] still practically unknown as a writer."18 
Looking back over those forty years of James's writings about Whitman, one can see significant changes in his understanding of the poet. In 1868, Holmes wrote James of the arrival of spring and all its pleasures, e.g., " $[\mathrm{t}]$ he icy teeth have melted out of the air. . . . Now are the waters beneath my window of a deeper . . . blue. . . . Now couples . . . draw near to each other in the dark spaces between the gas lights and think themselves unseen." 19 Young James empathizes in his response, including in his description of his surroundings some randy remarks about a nearby woman washing windows. James's specific reference to Whitman seems mostly to allude to the erotic portion of Holmes's letter: "heaven reward you for this inspired effusion. . . . It runs through the whole circle of human energy, Shelley, Kant, Goethe, Walt Whitman, all being fused in the unity of your fiery personality." 20

Beginning with his first published essays in the 1870s, James relies on a Whitman who is no longer the Sensualist but the Absolutist. In an unsigned 1875 Nation review entitled "German Pessimism," James writes that while Schopenhauer and others like him might "exert a spell over persons in the unwholesome sentimental moulting-time of youth ... the existence of a Walt Whitman confounds Schopenhauer." ${ }^{21}$ Describing this absolute optimism again in an 1879 essay, "The Sentiment of Rationality," James writes that "we are in a sort of anaesthetic state in which we might say with Walt Whitman, if we cared to say anything about ourselves at such times, 'I am sufficient as I am." "'22 In the 1892 lecture "On a Certain Blindness in Human Beings," James dedicated nearly a quarter of his lecture to explaining how Whitman, the "hoary loafer," was able "simply to absorb [his] mind" in "the human crowd." 23 And in the opening pages of the 1895 "Is Life Worth Living?," James begins this way:

With many men the question of life's worth is answered by a temperamental optimism which makes them incapable of believing that anything seriously evil can exist. Our dear old Walt Whitman's works are the standing text-book of this kind of optimism. The mere joy of living is so immense in Walt Whitman's veins that it abolishes the possibility of any other kind of feeling. ${ }^{24}$

James then declaims thirteen lines from "Song at Sunset" (e.g., "To breathe the air, how delicious!"; "To be this incredible God I am!") and concludes that Whitman's soul was "incapable . . of gloom." 25

Sometime around 1900, however, James's view of Whitman changed once more. Writing the lectures later to become The Varieties of Religious Experience, James seems to have discovered that Whitman's optimism was not at all temperamental, but hard-won, involving the difficult work of picking the right details from the intense pluralism of experience. In the lecture "The Religion of Healthy-Mindedness," for example, James begins by citing a passage from Bucke's book Cosmic Con- 
sciousness, arguing that anger and like emotions were simply absent in Whitman. But James then comments that "Walt Whitman owes his importance in literature to the systematic expulsion from his writings of all contractile elements." 26 James goes on to criticize not only this worship of Whitman as a perfect Christ (and he refers to Traubel's The Conservator) but also the reduction of Whitman to a "pagan" (alluding here to George Santayana's attack on Whitman and Robert Browning in his recent book, Poetry of Religion). Whitman is no Christ, James argues, nor is he a pagan: he is more than "your mere animal man who has not tasted of the tree of good and evil." Whitman, James points out, "is aware enough of sin for a swagger to be present in his indifference towards it, a conscious pride in his freedom from flexions and contractions, which your genuine pagan . . . would never show."27 Whitman's "optimism is . . . voluntary and defiant," and "his gospel has a touch of bravado and an affected twist." ${ }^{28}$ In a letter to a friend from the same time, James objected to Santayana's conclusion that the realism of contemporary poetry represented a barbaric betrayal of poetry's representation of the ideal:

Dramatic unities; laws of versification; ... scholastic doctrines. Bah! Give me Walt Whitman ... ten times over. .. . The barbarians are in the line of mental growth, and those who do insist that the ideal and the real are dynamically continuous are those by whom the world is to be saved. ${ }^{29}$

Quite aware, then, of both the deification and paganization schools of Whitman critics, James boldly takes Whitman in another non-absolutist, pragmatist direction, arguing that the poet's deliberate selection of possibles from the welter of human experience is prototypically modern, the start of a second reformation. Whitman is, in short, the kind of person "by whom the world is to be saved": the pragmatist.

Over the last thirty years, Richard Rorty has been the philosopher most responsible for pragmatism's new popularity, and it is instructive to compare his strategies to those of William James. Like James, Rorty only gradually persuaded people that pragmatism is the rightful tool of neither relativistic war-mongers nor absolutist (nowadays postmodernist) mystics but of progressive reformers; also like James, Rorty only gradually recognized Whitman as just the writer to help him make this case.

Through the 1970s and 1980s, when Rorty used philosophers like Heidegger rather than poets like Whitman to present pragmatism as an antifoundationalist philosophy, the progressive power of his pragmatism was frequently contested by critics. In 1982, when Rorty explained antifoundationalist pragmatism as "offer[ing] a view on pretty much 
anything, in the hope of making it hang together with everything else," critics responded as they once did to James: that this is either an apology for the warrior's status quo (in this case the Cold War warrior) or a retreat into postmodern escapism, or what Rorty unfortunately called in 1983 his "Post-Modernist Bourgeois Liberalism." ${ }^{30}$ In 1987, when Rorty confessed his regret for having used the term postmodernism to describe his pragmatism, and began to link his pragmatism more specifically to "social democra[cy]," his ambitions for the philosophy were still very modest: the social democrat was someone who cherished liberal institutions in the face of Soviet imperialism, especially when "time seems to be on the Soviet side." ${ }^{31}$ As it turned out, time was not on the Soviet side, and when 1989 brought the abrupt disappearance of communism in Eastern Europe, Rorty's pragmatism was at best only mildly progressive, concerned with promoting what he called the "liberal ironist," who spent his time privately "redescribing" himself since J. S. Mill had said "pretty much the last word" about public life in a liberal democracy. ${ }^{32}$

Since the end of the Cold War, however, Rorty has increasingly argued that there is in fact still work to do in the liberal public sphere. More and more, he has championed the progressive power of pragmatism, and he has learned-like James - to enlist Whitman in his cause. In a 1995 address to the MLA convention in Chicago, Rorty defended "The Inspirational Value of Great Works" against the "knowingness" of postmodern literary critics. Just as James once used Whitman to challenge self-satisfied absolutists to consider the power of pragmatism to pick its way through a pluralistic universe, Rorty used Whitman to challenge those "taking refuge in self-protective knowingness" to consider the power of a "pragmatist functionalism" that views literature as "mak[ing] people think there is more to this life than they ever imagined." 33 In a 1997 essay, "Religious Faith, Intellectual Responsibility, and Romance," Rorty defends the idea of "romance" as "a faith in the future possibility of mortal humans, a faith which is hard to distinguish from love for, and hope for, the human community," calling this romance in conclusion the "Whitmanesque dream of plural, democratic vistas." "34 In a 1998 forum of public intellectuals in American Literary History, Rorty described his own vocation to write for "fellow citizens" as "Whitmanesque." 35

But Rorty's most substantial and compelling use of Whitman is to be found in his 1997 William E. Massey, Sr., lectures in the history of American civilization, published in 1998. Here Rorty argues that the American political left has become nearly as fundamentalist or absolutist as the American right. Where too many on the right see America as part of God's divine plan, too many on the left, particularly the cultural left dominated by postmodern theories like Foucault's, see America determined entirely by an insidious "power." Both right and left are 
consequently trapped in "gothic" worldviews entirely of their own making. Like James, Rorty has set out to define a pragmatism that will demolish these absolutist delusions and focus instead on genuine possibles. And, like James, Rorty finds the great voice for this pragmatist program in Whitman. In the first lecture, "American National Pride: Whitman and Dewey," Rorty writes that "Whitman viewed the United States as an opportunity to see ultimate significance in a finite, human, historical project, rather than in something eternal and nonhuman. ... [He] wanted that utopian America to replace God as the unconditional object of desire." Rorty goes on to quote from Democratic Vistas that "democracy . . . is a great word, whose history . . . remains unwritten, because that history has yet to be enacted." 36

Like James, Rorty finds Whitman useful for teaching Americans a different kind of religion, one that sits somewhere between a crude, brutal naturalism and a passive, gothic absolutism. Even more than James, Rorty depends upon Whitman to vivify the progressive spirit of true pragmatism. As he was at the beginning of this century, Whitman seems once again at its end to be an indispensable voice of the culture of pragmatism.

\section{Daniel Webster College}

\section{NOTES}

1 Gay Wilson Allen, The Solitary Singer: A Critical Biography of Walt Whitman (New York: Macmillan, 1955), 390.

2 Quoted in Ralph Barton Perry, The Thought and Character of William fames (Boston: Little, Brown, 1935), 2:446.

3 Quoted in George Cotkin, William fames, Public Philosopher (Baltimore: Johns Hopkins University Press, 1990), 158.

4 Quoted in Cotkin, 207-208.

5 William and Henry fames: Selected Letters, ed. Ignas K. Skrupskelis and Elizabeth M. Berkeley (Charlottesville: University of Virginia Press, 1997), 486.

6 Quoted in Perry, 452-453.

7 William James, Writings 1902-1910 (New York: Library of America, 1987), 618, 619.

8 James, Writings 1902-1910, 606.

9 Charles B. Willard, Whitman's American Fame: The Growth of His Reputation in America after 1892 (Providence: Brown University Press, 1950).

10 James, Writings 1902-1910, 607-608.

11 James, Writings 1902-1910, 607.

12 James, Writings 1902-1910, 608. 
13 James, Writings 1902-1910, 608.

14 James, Writings 1902-1910, 608.

15 James, Writings 1902-1910, 608-609.

16 Henry James, "Mr. Walt Whitman," in Walt Whitman: The Contemporary Reviews, ed. Kenneth M. Price (Cambridge: Cambridge University Press, 1996), 115118.

17 Howells reviewed Drum-Taps for Round-Table in 1865; Norton reviewed Leaves of Grass for Putnam's Monthly in 1855. See Price, Walt Whitman: The Contemporary Reviews, 112-114, 14-18.

18 Willard, 17.

19 Quoted in Perry, 1:509.

20 Quoted in Perry, 1:512. James requested that Holmes not show the letter to his father and to "use your own judgment" as to whether to show it to Henry (1:518).

21 William James, The Works of William fames: Essays, Comments, and Reviews, ed. F. H. Burkhardt (Cambridge: Harvard University Press, 1987), 312-313.

22 William James, Writings 1878-1899 (New York: Library of America, 1992), 951.

23 James, Writings 1878-1899, 853, 851.

24 James, Writings 1878-1899, 480.

25 James, Writings 1878-1899, 481, 482.

26 James, Writings 1902-1910, 83.

27 James, Writings 1902-1910, 84.

28 James, Writings 1902-1910, 85.

29 Quoted in Perry, 2:320.

30 Richard Rorty, Consequences of Pragmatism (Essays: 1972-1980) (Minneapolis: University of Minnesota Press, 1982), xxxix; Richard Rorty, "Post-Modernist Bourgeois Liberalism," Fournal of Philosophy 80 (1983), 583-589.

31 Richard Rorty, "Thugs and Theorists: A Reply to Bernstein," Political Theory 15 (November 1987), 578, 565-567.

32 Richard Rorty, Contingency, Irony, and Solidarity (Cambridge: Cambridge University Press, 1989), xv, 63.

33 Richard Rorty, "The Inspirational Power of Great Works of Literature," Achieving Our Country: Leftist Thought in Twentieth-Century America (Cambridge: Harvard University Press, 1998), 128, 140, 136, 133. Rorty refers to Whitman on pages 138139.

34 Richard Rorty, "Religious Faith, Intellectual Responsibility, and Romance," The Cambridge Companion to William fames, ed. Ruth Anna Putnam (Cambridge: Cambridge University Press, 1997), 583-589, 596.

35 Richard Rorty, "Thinking in Public," American Literary History 10 (Spring 1998) 65, 64 .

36 Rorty, Achieving Our Country, 17-18, 19. 